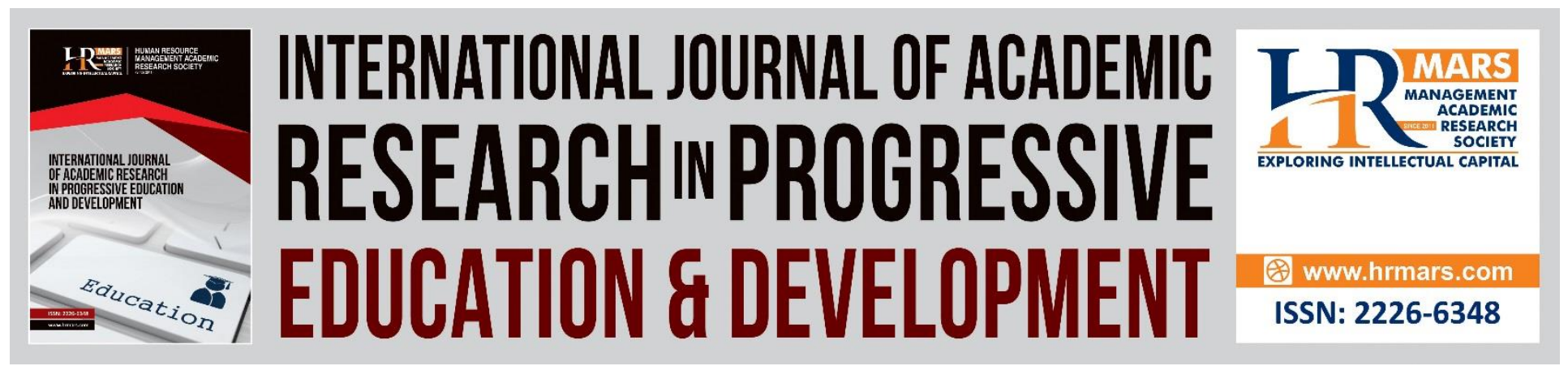

\title{
Teachers' Views on Integrating Environmental Education for Aboriginal Students
}

Norshariani Abd Rahman, Lilia Halim, Abdul Razaq Ahmad, Arba'at Hassan \& Tuan Mastura Tuan Soh

To Link this Article: http://dx.doi.org/10.6007/IJARPED/v7-i2/4080

DOI: $10.6007 /$ IJARPED/v7-i2/4080

Received: 28 March 2018, Revised: 25 April 2018, Accepted: 11 May 2018

Published Online: 15 May 2018

In-Text Citation: (Rahman, Halim, Ahmad, Hassan, \& Soh, 2018)

To Cite this Article: Rahman, N. A., Halim, L., Ahmad, A. R., Hassan, A., \& Soh, T. M. T. (2018). Teachers' Views on Integrating Environmental Education for Aboriginal Students. International Journal of Academic Research in Progressive Education and Development, 7(2), 16-29.

\section{Copyright: (C) 2018 The Author(s)}

Published by Human Resource Management Academic Research Society (www.hrmars.com)

This article is published under the Creative Commons Attribution (CC BY 4.0) license. Anyone may reproduce, distribute, translate and create derivative works of this article (for both commercial and non-commercial purposes), subject to full attribution to the original publication and authors. The full terms of this license may be seen

at: http://creativecommons.org/licences/by/4.0/legalcode

Vol. 7, No. 2, April 2018, Pg. 16 - 29

http://hrmars.com/index.php/pages/detail/IJARPED

JOURNAL HOMEPAGE

Full Terms \& Conditions of access and use can be found at http://hrmars.com/index.php/pages/detail/publication-ethics 


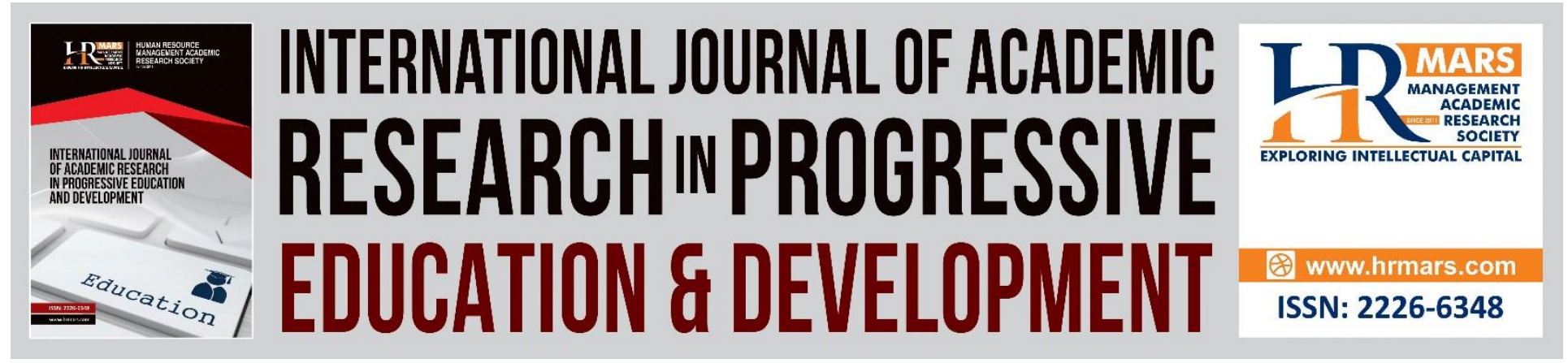

\title{
Teachers' Views on Integrating Environmental Education for Aboriginal Students
}

\author{
1a Norshariani Abd Rahman, ${ }^{2 b}$ Lilia Halim, ${ }^{2 c}$ Abdul Razaq \\ Ahmad, ${ }^{3 d}$ Arba'at Hassan \& ${ }^{2 e}$ Tuan Mastura Tuan Soh \\ ${ }^{1}$ Institute of Islam Hadhari, Universiti Kebangsaan Malaysia \\ ${ }^{2}$ Faculty of Education, Universiti Kebangsaan Malaysia \\ ${ }^{3}$ Faculty of Education, Open University Malaysia. \\ Email:anorshariani@ukm.edu.my, ${ }^{b}$ lilia@ukm.my, ${ }^{c}$ razaq@ukm.my, ${ }^{d}$ arbaat@yahoo.com, \\ etuanmastura@ukm.edu.my
}

\begin{abstract}
This study was investigate the teachers' views on integrating environmental education in terms of the definition, the importance, and the environmental education approach in aboriginal school. Data were collected through interviews using purposive sampling from six primary and six secondary school's teachers who were teaching in Aboriginal schools in Pahang, Malaysia. The verbatim transcript was analyzed manually based on incorporated the same code into several categories until the theme and sub-themes of the teachers' views emergence regarding the environmental education in aboriginal school students. Results showed that the teachers implemented environmental education through fostering of environmental values in subject taught, creating clean environment in classroom, writing essay related environment issues, and stimulating the students' thinking through observation. However, environmental awareness programs conducted by the schools are limited. Therefore, the teachers must have competencies in integrating environmental education through subject matter and established by the role of related stakeholders to aboriginal community.

Keywords: Environmental Education, Aboriginal Students, Teaching and Learning, Teachers', Competencies, Orang Asli

\section{Introduction}

Each individual is responsible in protecting the environment; including the Aboriginal people (United Nations, 1992). Aboriginal communities have an enormous role in maintaining environmental sustainability as highlighted in the Agenda 21 of Earth Summit Conference (United Nations, 1992; Palmer, 1998; Palmer \& Neal 1994). Aboriginal people are the closest community to the environment and they depend on the natural resources for survival (Harris, 2012; Salleh, 2012; Jelas, Ahmad \& Ayudin, 2009). In addition, they also have indigenous knowledge related
\end{abstract}


Vol. 7, No. 2, April 2018, E-ISSN: 2226-6348 @ 2018 HRMARS

to environmental management so that they live in harmony with the nature (Chandra 2014; UNEP, 2008). Their behaviours, cultures and beliefs are also highly dependent on the environment (Harris, 2012; Salleh, 2012; Jelas, Ahmad \& Ayudin, 2009).

In Malaysia, there have three main tribe of Aboriginal people i.e. Malay Proto, Senoi and Negrito. Each main tribe have their own sub-tribe and slightly different in terms of dialect of language (Jelas, 2009). The lives of aboriginal today are much different than in the past due to urbanization. The natural resources are not only used for their own needs, but also exploited by outside parties for commercially such as plants that have medicinal value and exotic animals (Nicholas \& Lasimbang, 2004). Changes lifestyle in conducting large-scale agriculture and Regrouping Plan (RP) caused the younger generation of Aboriginal peoples are no longer holding their environment-related customs, beliefs and practices as strong as before (Chopil \& Hunt, 2009). Consequently, knowledge heritage about traditional environmental management to the next generation is getting eroded (Nicholas \& Lasimbang, 2004) and the loss of Aboriginal's traditional culture prevents them from learning about the environment (Mallen et al., 2009). The impact of the decline of knowledge inherited by the new generation of Aboriginal students caused them have low environmental knowledge (Yusuf et al., 2005) and the involvement of Aboriginal people in environmental issues is still not enough (Rahman, 2010).

Thus, the school especially the teachers, play an important role in implementing environmental education to the new generation of Aboriginals in order to develop responsible environmental behaviors. This is to ensure their role in environmental management are still needed as well as strengthen their existing indigenous knowledge inherited by their ancestors. Due to fact that the environmental education is carried across the curriculum, the teachers should be competent in integrating environmental education contents in lesson in subject matter. In addition, environmental education also requires the support of environmental awareness programs conducted by schools and other stakeholders to develop environmental care behavior among aboriginal students.

Therefore, this study aims to investigate the implementation of environmental education by teachers in aboriginal schools based on their views of the environmental education definition, the significance of environmental education to Aboriginal students, the method of implementing environmental education in teaching and learning, and environmental awareness programs carried out by schools. The views of the teachers regarding integration of Environmental education is important because they are the implementers that will determine the effectiveness of the environmental awareness program or to articulate the implementation of government policies. In addition, this study should be done to gain more information on the actual situation occurring in the Aboriginal schools as well as providing solutions to solve problems related to environmental education.

\section{Literature Review}

The environmental education was established for the purpose of increasing knowledge, awareness and behaviours towards environmental protection. However, the lingering environmental problems and irresponsible behaviours towards the environment among the 
Vol. 7, No. 2, April 2018, E-ISSN: 2226-6348 @ 2018 HRMARS

community bring many questions about the effectiveness of environmental education. Previous research has been reported that environmental education conducted across the curriculum have three main challenges; i. developing an environmental education with a clear track, ii. approaches in implementing environmental education and iii. materials and effective training methods for educators (Rozita, 2001). Moreover, environmental education is often overlooked in teaching and learning in schools because it is not included as a test in school (Shaari, 2009).

Teachers' perceptions of the concept and significance of environmental education is very important in creating teachers' motivation to integrate environmental education in learning and teaching. Previous research has revealed that the school's goals and philosophy of the environmental education are unclear (Pace, 2003). Thus, learning activities that emphasize environmental education are not given priority in schools and during the process of teaching and learning by teachers (Samuel, 1993 \& Pace, 2003). The teachers are not applying the elements of environmental education in their teaching because they believe that the concept of environmental education has no connection with the subject being taught (Samuel, 1993; Lane et al., 1994). Teachers think that only Science subject is connected to environmental education and only Science teachers should be responsible to apply environmental education. Lack of cooperation and communication between teachers of different subjects also caused failure in the implementation of environmental education (Kin, 2004). However, environmental education is actually a multi-disciplinary in nature and should be taught across the curriculum (Hungerford et al., 2005).

In the context of aboriginal students, they need fun-learning instructional strategies because they easily get bored (Mamat et al., 2012). Consequently, learning strategies have an impact on the achievement of learning objectives. Therefore, interesting and effective teaching aids must also be emphasized by teachers in planning lessons. Teaching and learning of environmental education approach have been used in previous research are problem solving, experiment, fieldwork, simulation, module and imitation (Erdogan, 2011; Hungerford et al., 1990; Palmer, 1998). The methods used by the teachers are highly dependent on the creativity of teachers in lesson planning (Moseley et al. 2002). Biermann (2008) has been highlighted three criteria of aboriginal pedagogies in environmental education i.e. experiential-based learning, group-dynamic learning and students oriented. Therefore, it is important to review the teaching strategies and teaching aids used by the teachers in implementing the environmental education specifically for Aboriginal students in order to achieve the objectives of the environmental education.

Furthermore, teacher must have competency in integrating environmental education in teaching and learning. May (2000) claims that in environmental education, teachers must have competencies in basic knowledge, basic skills and competencies in integrating environmental education with subject taught. In addition, there have four types of content competencies i.e. basic concept of ecology, conceptual awareness, investigation and evaluation of environmental issues as well as environmental action skills (Hungerford and Volk, 1990; May, 2000). The teachers' content competencies in environmental education must be relevant to aboriginal 
Vol. 7, No. 2, April 2018, E-ISSN: 2226-6348 @ 2018 HRMARS

cultures in order to enhance students' environmental awareness that suit the reality life of aboriginal people.

The role of integrating the environmental education should not be placed entirely on the teachers. The school administrators and external agencies such as the Department of Aboriginal Development, Department of Environment, universities, and non-governmental organizations also should provide support to carry out activities related to environmental awareness in order to foster environmental awareness and behavior among Aboriginal students. The lack of support from these parties will be caused the limitation in implementation of environmental education program.

\section{Research Methodology Study Context}

The objectives of the study were to explore; i. teachers' view of the environmental education definition, ii. the significance of environmental education to Aboriginal students, iii. the method of integrating environmental education in teaching and learning, and iv. the environmental awareness programs carried out in schools. This descriptive case study utilized the semistructured interview method to obtain data from the teachers who are teach aboriginal students in primary and secondary school. The location of the study was in the state of Pahang, Malaysia. The school involved in this study is considered as a rural school.

\section{Participant}

The process of determination and selection of participants was based on the purpose and questions of the study. Thus, purposive sampling was used in this study to ensure that participants were able to provide the information required to answer the research questions (Patton, 2001). The participants were teachers teaching at aboriginal schools in Pahang state, regardless their teaching subject because environmental education has been implemented across the school curriculum in Malaysia. There were six (6) primary school teachers and six (6) secondary school teachers involved in the study. Purposive sampling method was applied to obtain data from the selected participants. The selection of the participants was based on the willingness of teachers to be actively involved in interview. They are known as PT1, PT2, PT3, PT4, PT5, and PT6 for represent primary school whereas the ST1, ST2, ST3, ST4, ST5 and ST6 represent secondary school. The respondents varied in terms of their educational background and the subject taught.

\section{Data Collection Procedure}

The researcher held preliminary meeting with the participants to explain the purpose of the study and to get the permission to conduct the interview. The researcher confirms the date and time of the interview with the participants according to the availability of the participants. The researcher begins by building rapport with the participants first so that the participants are prepared mentally and physically to provide the information based on the research questions. The researcher also informed the participants that the study required interview to be recorded. Therefore, a letter of authorization and acknowledgment as a participant must be signed 
INTERNATIONAL JOURNAL OF ACADEMIC RESEARCH IN PROGRESSIVE EDUCATION AND DEVELOPMENT

Vol. 7, No. 2, April 2018, E-ISSN: 2226-6348 @ 2018 HRMARS

voluntarily by the participant. The preparations were made to ensure that the interview went well.

\section{Data Analysis Procedure}

The data analysis is a critical process in which the data was collected through various methods of analysis. All data were obtained from semi-structured interview. After the interview was conducted, the researcher created a transcript of the interview. The verbatim transcript was further analyzed manually. The researcher built the open coding for each verbatim and then incorporated the same code into several categories. The process continues until the theme and sub-themes of the teachers' views emerged in terms of the definition of the environmental education, the importance of environmental education on the Aboriginal students, the method of integrating environmental education in teaching and learning, and environmental awareness programs conducted by the school.

\section{Research Findings}

\section{Background of the Participants}

A total of six (6) in primary school teachers and six (6) secondary school teachers from Aboriginal schools were interviewed in this study. One of the teachers who were interviewed in this study is an Aboriginal (PT1). It was found that of the 12 teachers interviewed, 3 of them had attended courses related to environmental education during their studies. PT1 and PT3 attended the Outdoor Education course during their college. This Outdoor Education combines the elements of recreation and environmental education through the activities carried out within a specific environment such as jungle-trekking and kayaking. ST5 have a degree in Environmental Science. Therefore, ST5 had more exposure to the elements related to the environment. Nine (9) of the remaining teachers had never attended any courses related to environmental education neither during their studies nor in-service.

PT1: "There is no special course, there is a subject of Outdoor Education. That is the recreation, go trekking, kayaking ... during trekking look at plants and environment ..."

PT3: "Outdoor. In the college there is an outdoor education... go to Redang Island ... recreation, at the same time learning about the environment....then I go trekking, ...show of plant trees ..."

\section{Teachers' Perceptions of Environmental Education}

There are different perceptions of teachers regarding environmental education. Most of them view environmental education as a means to cultivate the values of recognizing, conserving, appreciating, and maintaining the environment (PT1, PT3, PT5, PT6, ST1, ST2, ST4, ST5 and ST6). There are also teachers who view environmental education as understanding the inter-relation or human relationship with the environment (PT1, ST3 and ST4). In addition, a teacher (PT4) understands environmental education as cleanliness and cheeriness.

PT1: "To know our nature around us, we have to know the contribution of environment, what we need to do to protect nature". 
INTERNATIONAL JOURNAL OF ACADEMIC RESEARCH IN PROGRESSIVE EDUCATION AND DEVELOPMENT

Vol. 7, No. 2, April 2018, E-ISSN: 2226-6348 @ 2018 HRMARS

PT3: "Environmental education is more about applying values about environment protection from being destroyed ".

ST1: "Environmental education teaches us to appreciate the beauty of the environment".

ST2: "Education about the importance in maintaining environmental hygiene conservation and maintaining the natural treasures that God bestowed ".

PT1: "...that's our relationship with the environment ... ".

PT4: "About cleanliness, cheerfulness...all it's "

\section{Importance of Applying the Environmental Education to Aboriginal Students}

All the teachers involved in this study acknowledged that environmental education among Aboriginal students is important. This is because the lives of Aboriginal people depend on the forests or the environment (PT1, PT6, ST5 and ST6). Damage to the environment will affect the economy of Aboriginal people (PT1).

PT1: "It is important because most Orang Asli communities live more in the forest area ... the forest area is getting much less, the source is getting worse ... disturbing their economy, at the same time it will cause extinction."

PT6: "it's important because of the lifestyle of Orang Asli related to environment".

ST5: "The Orang Asli depends on nature resources and forest is the place for them stay".

ST6: "Yes, because they used the nature resources in everyday activities for survival ".

In addition, the environmental education is important to preserve indigenous knowledge about the environment (PT3), develop awareness of the environment (ST1, ST2, ST3 and ST4), and the ability to participate in protecting the environment (PT5 and ST4). Environmental education is also important to preserve the heritage (PT2) and to be shown to future generations (PT1). PT4 teacher sees that the environmental education is important to motivate students to learn if the environment is clean and cheerful.

PT3: "The environment is important and necessary, now they have basic knowledge about environment. But we need to reinforce it".

ST2: "give awareness to Orang Asli community about environmental care ...".

PT5: "It is important that students can be exposed from the beginning how they can protect the environment ..."

ST1: "We need a reserved forest to show for future generation..."

PT4: "It is important because if the environment is not clean and beautiful, the passion

for learning does not exist ...".

\section{Integrating Environmental Education in Teaching and Learning}

Teachers have implemented the environmental education in their teaching and learning either directly or indirectly. The most applied approach by the highest number of teachers was through 
INTERNATIONAL JOURNAL OF ACADEMIC RESEARCH IN PROGRESSIVE EDUCATION AND

DEVELOPMENT

Vol. 7, No. 2, April 2018, E-ISSN: 2226-6348 @ 2018 HRMARS

the fostering of values that encourage caring for the environmental through the environmental topics taught (PT5, PT6, ST2, ST3, ST4, ST5 and ST6) or as advice (PT1, PT2, PT3, PT4).

ST2: "infusing environmental values in moral education and arts".

PT2: "how to protect the environment, what is to be done and what is be prohibited towards

environment...include some of the environmental values"

PT4: "During teaching, we teach how to keep the hygiene... when the students back home, we

also remind them... at their study place and clothes..."

In addition, teachers also create clean environment of teaching and learning by asking their students to collect rubbishes and clean the classroom before teaching and learning session (PT1, PT2 and PT3) as stated below:

PT1: "must smart, beautiful, clean the whole body and classroom as well. If not, we allocate

one hour for cleaning ...Learning is number two...because we emphasize on cleaning first".

PT2: "First word when I enter the classroom, pick up the rubbish. This is my first word".

PT3: "in half in hour, I would check every class...clean or not".

For language teachers (PT2 and PT4), they applied environmental education through the vocabulary or by using the environmental elements terms such as names of plants and animals in English and also Arabic. There are also language teachers who implement environmental education through essay writing on environmental issues (PT3 and ST3).

PT2: "In English, there are have a topic of plant... we integrate in vocabulary..."

PT4: "names.... before teach we introduce the vocabulary in plants, vegetables, fruits in arabic language".

PT3: "essay related to logging...but we have to help them by giving the content".

ST3: "story and clarify through essay".

Teachers also use newspaper clippings and photographs related to environmental issues to stimulate the students' thinking by asking questions about the causes and effects of occurring environmental problems (PT1, PT3).

PT1: "Sometimes at the papers that the students read, show pictures and ask the question why

floods happen? What the causes? Why?"

PT3: "Look at the picture of Klang river, ask them, is there any difference of this water with

water here? Why dirty?" 


\section{INTERNATIONAL JOURNAL OF ACADEMIC RESEARCH IN PROGRESSIVE EDUCATION AND}

DEVELOPMENT

Vol. 7, No. 2, April 2018, E-ISSN: 2226-6348 @ 2018 HRMARS

PT1 uses the method of observing the surrounding areas in explaining the effects of human actions on the environment by showing the exploited hills next to their school. PT3 implement environmental education in Physical Education with a tree as the theme to explain the interrelationships between plants and humans through the air breathed. PT3 teacher also stimulates the students to think by providing comparative situations such as telling the students to think of what will happen if a paper and plastic is exposed to rain and sun. The aim is to enlighten the students on how to select a more environmental-friendly packaging.

PT1: "they can look around, just like there have been bald (while point out towards the hill at the edge of the school area). Then, we teach the effect, ask question

why...usually relate to their everyday life, so that they can see what happen

to

themselves..."

PT3: "at the Physical education, I said to them. If we make exercise in the morning, we inhale Oxygen. In the morning our brain will be fresh because we get fresh oxygen

from tree. The tree produces oxygen and absorb carbon dioxide. As human beings,

we inhale oxygen and exhale carbon dioxide. so we switch the need.. That means that

the tree is important for our life. Sometimes I have to sit down under tree and ask the

students to take a breath".

PT3: "Try to leave a plastic for a month, see it under rain or sun, will be degradable

or not? Then, try put paper under the rain.. My point is to show the difference and

to reduce the plastic use"

\section{Programs Related to Environmental Education}

Results showed that the schools have organized certain programs of environmental awareness. However, the frequency is less and inconsistent. Among the activities were recycling (PT1, PT2). The school recycles milk cartons consumed by students during the 1Malaysia milk program. There are also activities that make use of recycled bottles to make a flag at the school gate, and as decorations in the school.

PT1: "recycling...because at school we use paper only. Usually after 1 Malaysia Milk program we collect all the milk boxes. In the first time, we explain to student to sell the boxes at recycle center".

PT2: " So far, there only two program for recycling. ..We far from the city, so it's hard.

It's not worth it because we just get two ringgit for the all milk boxes...Last 
INTERNATIONAL JOURNAL OF ACADEMIC RESEARCH IN PROGRESSIVE EDUCATION AND DEVELOPMENT

Vol. 7, No. 2, April 2018, E-ISSN: 2226-6348 @ 2018 HRMARS

program we also collect the bottle to make a flag".

Other than that, awareness programs using posters (PT2, PT3, and PT5) related to the environment and environmental quizzes (PT5) are also organized by the schools. Mutual cooperation to clean up the school (PT4, PT5, PT6, ST1, ST2 and ST3) and rubbishes cleaning programs in the school before teaching and learning (PT1, ST4) are also carried out. The programs are aimed at promoting hygiene practices in schools.

PT2: "there's a poster competition, but not every year"

PT3: "Usually make a poster, or just give a poster related to environment and ask the

students to colour it".

PT4: "There is a gotong royong involving the whole school including the student and

teacher. Twice a year".

PT1: "before 7.30, students will collect the rubbish at school. We want to be a good practice. Sometimes in 10 minutes...every day... must practice every day...".

In addition to that, planting trees (PT1, PT4 and PT5), making herb garden (ST4) and decorating the garden adopted by their clubs or associations (ST3, ST6) are also carried out in schools. In ST5's school, there are community service activities to clean the beach and recreation park for students.

PT1: "Senior teachers had planted tree...one time only. It like a environmental campaign..." PT4: "Sometimes, they plant vegetable. Plant at the backyard".

ST3: "Planting tree and decorate the adopted park according to their club".

ST5: "Community service activity...clean the beach or make a recreation park..."

\section{Discussions and Implications}

Overall, only three teachers were exposed to courses related to the environmental education during their studies while all the teachers have not received any in service courses related to application of environmental education. This makes the teachers less knowledgeable in planning their teaching to integrate environmental education in the topics being taught. This situation coupled with the absence of the teachers' handbook on environmental education across the Curriculum that has been issued by the Ministry of Education (MOE). This shows that the efforts made by the Ministry of Education are useless because the book did not reach the schools and the teachers. In fact, all the teachers involved in this study are not aware of the existence of the book. Similar findings were recorded by Shaari (2009) who found that 75 per cent of teachers are not aware of the existence of this handbook. The absence of handbooks caused the teachers to look for environmental information sources through the internet, newspapers, magazines, and electronic media such as television and radio.

Teachers' opinions about the importance of implementing environmental education were heavily influenced by their perceptions of the purpose of environmental education. All the teachers in this study recognizes the importance of environmental education for Aboriginal students and they have a proper understanding of the concept of environmental education as 
Vol. 7, No. 2, April 2018, E-ISSN: 2226-6348 @ 2018 HRMARS

outlined by the O'Riordan (1981) and Hungerford et al. (2005); environmental education is related to promote an environmental ethics. Hence, the matter that teachers think and believe will impact in shaping the students' learning experience (Shaari, 2009).

Teachers apply environmental education directly or indirectly in their teaching and learning, in their own way, creativity and usage of teaching aids. However, most teachers do not use teaching aids that are specialized in implementing environmental education. Teachers only use the newspapers to show the environmental issues as well as using the school environment situations indirectly. The use of more eye-catching teaching aids facilitate is important to facilitate students' understanding of what they are learning more clearly and quickly. Besides that, the teachers also using observation the surrounding areas and stimulate thinking skills about environmental problem that are related to Aboriginal students. From that, it will arise the curiosity of students and stimulate investigative thinking about environmental issues among aboriginal students.

In addition, teachers should plan learning strategies for environmental education for a more fun-learning. This is because Aboriginal students prefer teachers to use in fun-learning approaches such as games and singing (Mamat et al., 2012). Teachers also need to be skilled in the use of creative and appropriate teaching approaches. Teaching approaches such as outdoor learning, hands-on, experiment, role playing, simulation and activities-based learning are suitable for Aboriginal students (Erdogan, 2011; Hungerford et al., 1990; Palmer, 1998). This is because the approach provides an opportunity for students to apply what they have learned in reality with more fun which fits the easily-bored attitude of students in learning. Construction of teaching and learning modules for environmental education can also help Aboriginal students acquire the knowledge and skills to take positive actions for the environment. A more structured and brief learning modules facilitate Aboriginal students to learn about the environment and can also improve their performance in other academic areas.

In order to enhance integrating environmental education, teachers need to be confident and capable of incorporating environmental education pedagogical practices and learning activities in the classroom (Bodzin et al. 2010). Teachers also need to be more sensitive to develop learning strategies to increase the level of cognitive, affective, behavioural, and help students to achieve environmental literacy. Therefore, teachers need competency in selecting, using and implementing environmental education curriculum, knowledge of environmental issues and concepts, the ability to investigate and evaluate environmental issues as well as knowledge and skills in taking environmental actions (Bodzin et al. 2010). Moreover, the teachers should know the aboriginal's belief about environment and integrate this element to environmental education. In that case, it will motivate the aboriginal students to learn about environmental education because the beliefs is relate to their culture, custom and practices. In addition, the beliefs of aboriginal about the environment is seen as a key element for controlling their actions towards the environment (Department of the Orang Asli Affairs, 2011; Rahman, 2016. Salleh, 2004; UNEP, 2008).

Teaching and learning of environmental education and environmental awareness programs will be more effective if it combines the concepts of environmental science learnt in 
DEVELOPMENT

Vol. 7, No. 2, April 2018, E-ISSN: 2226-6348 @ 2018 HRMARS

schools with the knowledge of the local environment (indigenous knowledge) existing among Aboriginal people. Therefore, ethnobiologists should work together with the environmentalists in planning environmental programs especially for Aboriginal people in general and Aboriginal students in particular. Teachers need to adopt a strong commitment to apply environmental education because the strong commitment shown by the teachers will reduce the perceived constraints in the execution of environmental education. This in turn will ensure the effectiveness of environmental education in changing students' behaviours in making them more concerned about the environment.

Aboriginal students are still lagging behind in education compared to other ethnic groups. Thus, the emphasis is more focused on the aspects of educational development. In terms of cleanliness and cheeriness aspects of the school, Aboriginal students remained at a low level (Ahmad, Kassim \& Jelas, 2011). As a results, the teachers take a long time to cultivate awareness of environmental care because personal hygiene aspects are given attention prior to comprehensive classroom hygiene and environmental care aspects. Humility, less selfconfidence in themselves and absence of religion stance among Aboriginal students also has implications on their behaviours towards the environment.

The schools should be active in implementing environmental awareness programs consistently such as recycling, mutual cooperation, planting of trees, make compost fertilizer and garbage collection in the school before the start of the teaching and learning sessions. The schools also must participate in LESTARI school programs that educate students to love the environment and transform it with eco-friendly school environment. The Ministry of Education should play their role by providing environmental education courses especially for the teachers in order to guide those teachers in planning the lesson and incorporating the contents of the lesson with environmental education. Lack of support from the administration and other stakeholders such as Department of Orang Asli Development, Ministry of Education and universities also contribute towards the limitation in implementation of Environmental education program. Environmental education is not only dependent on the teachers in their teaching and learning process, but it also requires more robust environmental awareness programs from various quarters. This is because the results showed that external agencies did not come to school carrying environmental awareness programs.

\section{Conclusion}

This study attempts to explore teachers' views on the environmental education definition, the significance of environmental education to Aboriginal students, the method of integrating environmental education in teaching and learning, and the environmental awareness programs carried out in schools. Based on findings, teachers implemented environmental education through fostering of environmental values in subject taught, creating clean environment in classroom, writing essay related environment issues, and stimulating the students' thinking through observation. However, the constraints faced by the teachers and schools in implementing environmental education makes the implementation of environmental education restricted and inconsistent although teachers recognize the importance of it on Aboriginal students. Therefore, the related teachers should have the competence and commitment in 
Vol. 7, No. 2, April 2018, E-ISSN: 2226-6348 @ 2018 HRMARS

planning their teaching to suit the topics relevance with environmental education. Ministry of Education also should support the integrating environmental education in schools by allocating budget for outdoor fieldwork in order to expose students in real environmental problem. For future research, we recommend to investigate the implementation of environmental education from students' views including their parents' role. This future research will provide the valuable understanding how the students learn about environmental education and how they apply the environmental knowledge to protect the environment in their life. This is because Aboriginal students have their own unique beliefs related to nature environment and they play a crucial role in ensuring the environment sustainability. Integrating environmental education in subject matter will help students to demonstrate positive environmental behavior.

\section{References}

Ahmad, A. R., Kassim, Z. \& Jelas, Z. M. (2011). Competencies of social intelligente among Orang Asli in Malaysia. Proceeding of International seminar Education Comparative in Curruculum for Active Learning Between Indonesia and Malaysia, 519-528. Indonesia: Universiti pendidikan Indonesia.

Biermann, S. (2008). Indigenous Pedagogies and Environmental education. International Journal of Pedagogies and Learning, 4(3), 27-38.

Bodzin, A. M., Klein, B. S., \& Weaver, S. (2010). The Inclusion of Environmental education in Science Teacher Education. Springer. New York: London.

Chandra, D. V. (2014). Re-examining the Importance of Indigenous Perspectives in the Western Environmental Education for Sustainability : From Tribal to Mainstream Education. Journal of Teacher Education for Sustainability, 16(1), 117-128. http://doi.org/10.2478/jtes-20140007

Chopil, T. Y. \& Hunt, B. T.W. (2009). Orang asli and environment. Retrieved on 1 March 2010 from www.perakspeak.com.

Department of the Orang Asli Affairs. (2011). Retrieved from jakoa.gov.my [1 December 2011].

Erdogan, M. (2011). The Effects of Ecology-Based Summer Nature Education Program on Primary School Students' Environmental Knowledge, Environmental Affect and Responsible Environmental Behavior. Educational Sciences: Theory \& Practice, 11 (4), 2233-2236.

Ham, S. H. \& Sewing, D. R. (1998). Barriers to environmental education. The Journal of Environmental education, 19 (2), 17-23.

Harris, F. (2012). Global Environmental Issues. $2^{\text {nd }}$ edition. UK: Wiley-Blackwell.

Hungerford, H. R. \& Volk, T.L. (1990). Changing learner behavior through Environmental Education. Journal of Environmental education, 21 (3), 8-21.

Hungerford, H. R., Bluhm, W.J., Volk, T.L \& Ramsey, J. M. (2005). The Tbilisi Declaration. Essential Readings in Environmental education. $3^{\text {rd }}$ Edition. Champaign, Illinois: Stripes Publishing.

Jelas, Z.M., Ahmad, A. R. \& Ayudin, A. R. (2009). The Orang Asli People: Educational and Sociocultural Views. Bangi, Malaysia: National University of Malaysia.

Kin, C. (2004). Survey of primary and secondary school teacher's teaching competencies for environmental education in Xicheng distric of Beijing. Chinese Education and Society, 37 (4), 39-44. 
INTERNATIONAL JOURNAL OF ACADEMIC RESEARCH IN PROGRESSIVE EDUCATION AND

DEVELOPMENT

Vol. 7, No. 2, April 2018, E-ISSN: 2226-6348 @ 2018 HRMARS

Lane, J. Wilke, R. Champeau, R., \& Sivek, D. (1994). Environmental education in Wisconsin: A teacher survey. The Journal of Environmental Education, 25 (4), 9-17.

Mamat, W. H. Ahmad, A.R., Abdullah, R. \& Seman, A.A. (2012). Students; views of schools and Education. Proceeding of International Conference of Education Comparative in Competency Based Curruculum Between Indonesia and Malaysia, 419-434. Indonesia: Universiti pendidikan Indonesia.

Moseley, M. (2000). Teaching for environmental literacy. Clearing House, 74 (1), 23-24.

Nicholas, C. \& Lasimbang, J. (2004). Biodiversity \& indigenous knowledge system in Malaysia. Subang Jaya, Malaysia: Center for Orang Asli Concern.

O' Riordan, T. (1981). Environmentalism. London: Pion Limited.

Pace, P.J. (2003). Environmental Education: Providing a context for a meaningful Science education. Journal of Baltic Science Education, 1, 28-35.

Palmer, J. A. (1998). History and development of environmental education. Environment Education in the $21^{\text {st }}$ century. theory, practice, progress and promise. London: New Fatter Lane.

Palmer, J., \& Neal, P. (1994). The handbook of environmental education. London: New Fatter Lane.

Patton, M. Q. (2001). Qualitative Research and Evaluation Methods. $3^{\text {rd }}$ ed. California: Thousand Oak Sage.

Rahman, H. A. (2010). The involvement of the native people in environmental issues: A survey on the Mah Meri Tribe in Carey Island, Kuala Langat, Selangor. Human Science Journal, 17, 114134.

Rahman, N. A. (2016). 2016. Knowledge, Internal, And Environmental Factors On Environmental Care Behaviour among Aboriginal Students In Malaysia. International Journal of Environmental and Science Education, 11 (12), 5349-5366.

Salleh, H. (2012). Establishing researches on the Malaysian indegenous people. Inaugural Lecture Tun Sri Lanang Library. Bangi: National University of Malaysia Press.

Samuel, H. R. (1993). Impediments to implementing environmental education. The Journal of Environmental education, 25 (1), 26-29.

Shaari, M. Z. A. (2009). Integrating Environmental education in Geography Teaching in Secondary school: Knowledge, Attitude, Efficacy and Practices. Unpublished Doctorate Thesis. Bangi: The National University of Malaysia.

United Nations Environmental Programme (UNEP). (2008). Indigenous knowledge in disaster management in Africa. Retrieved from http://africanclimate.net/sites/defaults/files/indigenous\%20Booklet\%20UNEP.PDF. [28 August 2012].

United Nations. (1992). Agenda 21 chapter 36. Retrieved from http://www.undocuments.net/a21-36.htm [23 January 2008].

Yusuf, N., Ibrahim, N. I., Sulaiman, R., Mamat, R. (2005). Environmental knowledge and awareness among the aboriginal students. Proceeding of Managing the Environment National Seminar, 221-239. Bangi: National University of Malaysia. 